\title{
Material flow analysis of alternative biorefinery systems for managing Chinese food
} waste

Guo, Hanwen; Zhao, Yan; Damgaard, Anders; Wang, Qian; Lu, Wenjing; Wang, Hongtao; Christensen, Thomas Højlund

Published in:

Resources, Conservation and Recycling

Link to article, DOI:

10.1016/j.resconrec.2019.05.010

Publication date:

2019

Document Version

Peer reviewed version

Link back to DTU Orbit

Citation (APA):

Guo, H., Zhao, Y., Damgaard, A., Wang, Q., Lu, W., Wang, H., \& Christensen, T. H. (2019). Material flow analysis of alternative biorefinery systems for managing Chinese food waste. Resources, Conservation and Recycling, 149, 197-209. https://doi.org/10.1016/j.resconrec.2019.05.010

\section{General rights}

Copyright and moral rights for the publications made accessible in the public portal are retained by the authors and/or other copyright owners and it is a condition of accessing publications that users recognise and abide by the legal requirements associated with these rights.

- Users may download and print one copy of any publication from the public portal for the purpose of private study or research.

- You may not further distribute the material or use it for any profit-making activity or commercial gain

- You may freely distribute the URL identifying the publication in the public portal 
Accepted for publication in Resources, Conservation and Recycling

Material flow analysis of alternative biorefinery systems for managing Chinese food waste

Hanwen Guo ${ }^{1}$, Yan Zhao ${ }^{2}$, Anders Damgaard ${ }^{3}$, Qian Wang ${ }^{1}$, Wenjing Lu ${ }^{1}$ * , Hongtao Wang ${ }^{1}$, Thomas H. Christensen ${ }^{3}$, *

${ }^{1}$ School of Environment, Tsinghua University, 100084, Beijing, China

${ }^{2}$ School of Environment, Beijing Normal University, 100875, Beijing, China

${ }^{3}$ Department of Environmental Engineering, Technical University of Denmark, Miljøevej, 2800 Kgs., Lyngby, Denmark

*Corresponding author. School of Environment, Tsinghua University, Beijing 100084, China;

Email address: luwenjing@tsinghua.edu.cn (W.J. Lu)

"NOTE: this is the author's version of a work that was accepted for publication in Environmental Science \&Technology. Changes resulting from the publishing process, such as peer review, editing, corrections, structural formatting, and other quality control mechanisms may not be reflected in this document. Minor changes may have been made to this manuscript since it was accepted for publication. A definitive version is published in Resources, Conservation and Recycling, Vol. 149, 197-209., https://doi.org/10.1016/j.resconrec.2019.05.010 


\section{Material flow analysis of alternative biorefinery systems for managing Chinese food waste}

Hanwen Guo a, Yan Zhao b, Anders Damgaard c, Qian Wang a, Wenjing

$\mathrm{Lu}^{\mathrm{a}, *}$, Hongtao Wang a, Thomas H. Christensen ${ }^{\mathrm{c}, *}$

${ }^{a}$ School of Environment, Tsinghua University, 100084, Beijing, China

${ }^{\mathrm{b}}$ School of Environment, Beijing Normal University, 100875, Beijing, China

c Department of Environmental Engineering, Technical University of Denmark, Miljøevej, 2800 Kgs., Lyngby, Denmark

${ }^{*}$ Corresponding authors at:

School of Environment, Tsinghua University, Beijing 100084, China; Email address: luwenjing@tsinghua.edu.cn (W.J. Lu)

Department of Environmental Engineering, Technical University of Denmark, 2800 Kgs., Lyngby, Denmark; Email address: thho@env.dtu.dk (T.H. Christensen) 


\begin{abstract}
Consistent material and substance flow diagrams for five alternative biorefinery scenarios for treating Chinese food waste were obtained by combining reported experimental research data and material flow analysis. The biorefinery alternatives produced biogas, biomethane, bioethanol and biodiesel in various combinations. The compiled statistical data compiled showed that $100 \mathrm{t}$ of Chinese food waste could produce $16 \pm 1.1 \mathrm{t}$ of biogas as a single technology and that other advanced biorefinery concepts could produce $5 \pm 0.4 \mathrm{t}$ of biomethane, $4 \pm 1.6 \mathrm{t}$ of bioethanol and/or $3 \pm 0.2 \mathrm{t}$ of biodiesel. In terms of substance flow, biorefinery scenarios transfer up to $75 \%$ of the total initial carbon in the food waste into bioproducts, while $22 \%$ of carbon is emitted, primarily as carbon dioxide. The compost obtained by composting the dewatered digestate contained about $75 \%$ of input $\mathrm{P}, 27 \%$ of input $\mathrm{K}$ and $6 \%$ of input $\mathrm{N}$. About $15 \%$ of input $\mathrm{N}$ was lost to the air during composting. The remaining $\mathrm{C}, \mathrm{N}, \mathrm{P}$ and $\mathrm{K}$ were in the wastewater. Introducing biorefinery concepts to the management of Chinese food waste can facilitate the generation of high-value bioproducts. However, biorefinery concepts are technologically complicated and the energy consumption may triple relative to that of only biogas production. The issue of a considerably large liquid fraction in all cases still needs to be addressed. The material flow diagrams in this work constitute a consistent platform for assessing future scenarios for treating Chinese food waste from a technical, economical as well environmental perspective.
\end{abstract}

\title{
Key words
}

Food waste, biorefinery, material flow analysis, substance flow analysis, scenario inventory 


\section{Introduction}

Food waste (FW) is a major issue in waste management globally; according to the Food and Agriculture Organization of the United Nations more than $1.3 \times 10^{9}$ t of FW is generated around the world every year (FAO, 2018). In China, 130 million tonnes of FW are generated yearly and are mainly treated by anaerobic digestion with utilization of biogas for electricity and heat production. A range of other approaches has been proposed for FW treatment in China, and they include the use of a biorefinery concept in which biofuels are produced from FW (Wen et al., 2016).

The biorefinery concept is analogous to traditional petrochemical refinery that maximizes valuable outputs from the processing of crude materials (Lin et al., 2013). As refineries, biorefineries can provide multiple chemicals by fractioning an initial raw material (biomass) into multiple intermediates (carbohydrates, proteins, lipids) that can be further converted into value-added product (Cherubini, 2010).

Apart from the direct conversion of biogas into heat or electricity, which is a technology that already exists in full scale, other alternatives in the area of FW are attracting increasing attentions (Miezah et al., 2017; Hao et al., 2015; Sawatdeenarunat et al., 2016). The report of the International Energy Agency Bioenergy Task (IEA, 2012) gives a detailed list of potential value-added products, including bioethanol, biodiesel, succinic acid, lactic acid, levulinc acids, furfural alcohol and hydroxymethylfurfural. These products from FW has received strong support from researches in recent years (Coma et al., 2017; Gaudino et al., 2019; Lavelli et al., 2018; Rudroff and Chem, 2017; Sherwood and Shang, 2018; Yu et al., 2017).

Bioethanol and biodiesel production based on other organic substrates (corn, used cooking oils, etc.) has become available and biorefining of woody biomass has received much research attention. However, the biorefining of Chinese FW remains challenging because of the mixed organic content (carbohydrates, proteins and lipids) and the data available are scarce (Hao et al., 2015).

Tang et al., (2008) produced bioethanol and biogas from kitchen waste at laboratory scalel. Hao et al., (2015) established an integrated biorefinery process with outputs of biolipids and biogas via laboratory experiments. Field case studies have also been conducted in China with feasible results (Jin et al., 2015; Wen et al., 2016), but the information available about material and nutrient flows as well as amount of products produced is rudimentary and does not provide a consistent basis for comparing alternative FW biorefinery systems.

Our research aims to fill this research gap and provide a consistent framework for 
analyzing FW-based biorefinery exploitation routes. For the first time, this study provides a systematic analysis of the material and nutrient flows of a range of potential biorefinery concepts for treating Chinese FW. On the basis of a comprehensive survey of technical data from the literature and from technical reports, statistical distributions were established in this work to determine the key technical parameters. Material and nutrient flows were estimated for five scenarios for treating Chinese FW. The baseline scenario is anaerobic digestion as this technology is already in place in many areas of China. The four other hypothetical biorefinery scenarios aree modeled with biomethane, bioethanol and biodiesel in different combinations with anaerobic digestion. The material flow analysis, including the estimation of associated uncertainties, provides a systematic estimate of the quantity of products and residues generated by the biorefinery scenarios. The results should form an important engineering platform for assessing the future potential of biorefinery concepts for treating Chinese FW in technical, economic and environmental terms.

\section{Materials and methods}

This section describes how data on Chinese FW composition were obtained and how we defined the biorefinery technologies and compiled key data for the material and nutrient flow analysis.

\subsection{Composition of FW}

FW originates from households, canteens, restaurants, food shops and markets. The composition of Chinese FW is summarized in Table 1. Most of the data on FW composition come from canteens and restaurants. The water content ranges from $73 \%$ to $83 \%$, with the average being $79 \%$. Carbohydrates, proteins and lipids are the main components, averaging $51 \%, 16 \%$ and $22 \%$ of dry matter (DM), respectively. Whereas biogas is produced by anaerobic digestion of all three organic compounds, biodiesel is produced by converting lipids and bioethanol production requires carbohydrates to be saccharified into glucose.

Table 1. Composition of Chinese food waste

\begin{tabular}{|c|c|c|c|c|c|c|c|c|c|}
\hline $\begin{array}{l}\text { Source of } \\
\text { information. }\end{array}$ & $\begin{array}{l}\text { Water } \\
(\%)\end{array}$ & $\begin{array}{l}\text { TS } \\
(\%)\end{array}$ & $\begin{array}{c}\text { VS } \\
\text { (\% TS) }\end{array}$ & $\begin{array}{c}\text { Ash } \\
(\% \mathrm{TS})\end{array}$ & $\begin{array}{c}\text { Carbohydrate } \\
\text { (\% TS) }\end{array}$ & $\begin{array}{l}\text { Protein } \\
(\% \mathrm{TS})\end{array}$ & $\begin{array}{l}\text { Lipid } \\
\text { (\% TS) }\end{array}$ & $\begin{array}{c}\text { TC } \\
(\% \mathrm{TS})\end{array}$ & $\begin{array}{c}\mathrm{TN} \\
(\% \mathrm{TS})\end{array}$ \\
\hline (Ma et al., 2008) & 82.8 & 17.2 & 85.0 & 14.9 & 64.9 & 15.6 & 18.1 & - & - \\
\hline (He et al., 2012) & 81.7 & 18.3 & 87.5 & 12.5 & 35.5 & 14.4 & 24.1 & 48.4 & 0.8 \\
\hline (Sun et al., 2013) & 80.3 & 19.7 & 86.3 & 13.7 & 51 & 14.5 & 20.9 & - & - \\
\hline (Shen et al., 2013) & 77.4 & 22.6 & 79.2 & 20.8 & 41.9 & 14.7 & 28.9 & 30.3 & 2.6 \\
\hline (Zhang et al., 2013) & 81.5 & 18.5 & 91.9 & 8.1 & - & - & 22.8 & 46.5 & 2.2 \\
\hline (Zhou et al., 2014) & 77.3 & 22.7 & 91.2 & 8.8 & - & - & 30.4 & 48.3 & 2.6 \\
\hline (C. Wu et al., 2015) & 72.8 & 27.2 & 93.8 & 6.3 & 61.1 & 23.0 & 13.2 & - & - \\
\hline
\end{tabular}




\begin{tabular}{lccccccccc} 
(Yong et al., 2015) & 79.9 & 20.1 & 95.8 & 4.2 & 40.6 & 14.0 & 25.3 & - & - \\
(Li et al., 2016) & 80.9 & 19.1 & 93.2 & 6.8 & 61.8 & 13.2 & 18.3 & 46.1 & 3.2 \\
Average & $\mathbf{7 9 . 4} \pm \mathbf{2 . 9}$ & $\mathbf{2 0 . 6} \pm \mathbf{2 . 9}$ & $\mathbf{8 9 . 3} \pm \mathbf{4 . 9}$ & $\mathbf{1 0 . 7} \pm \mathbf{4 . 9}$ & $\mathbf{5 0 . 9} \pm \mathbf{1 0 . 9}$ & $\mathbf{1 5 . 6} \pm \mathbf{3 . 1}$ & $\mathbf{2 2 . 4} \pm \mathbf{5 . 2}$ & $\mathbf{4 3 . 9} \pm \mathbf{6 . 9}$ & $\mathbf{2 . 3} \pm \mathbf{0 . 8}$ \\
\hline
\end{tabular}

TS: total solid; VS: volatile solid; TC: total carbon; TN: total nitrogen

\subsection{Data collection and analysis}

Data on the parameters related to bioprocesses were extracted and compiled from a range of sources: scientific literature, technical reports, statistical yearbooks and in a few cases supplemented by specific sampling and theoretical calculation. The latter was needed for the estimates of energy uses in full-scale plants where actual data were missing or only available for laboratory experiments. The statistical distributions of the related parameters (i.e., biogas yield, carbohydrate saccharification ratio, solid liquid separation ratio, glucose fermentation ratio and yield of transesterification) were established to estimate average flows and their associated uncertainties (average \pm standard deviation). The parameters are shown in Table 2 together with their sources. Additional information is available in the Appendix A, B and C. The technologies and the most critical technical parameters are summarized in the subsequent sections.

\subsection{Biogas production}

The technology route for biogas production is well known and could be described as two main sub-processes: anaerobic digestion and digestate dewatering (Fuldauer et al., 2018). After digestate dewatering, the liquid and solid fractions (SFs) of the digestate are utilized separately. Each fraction of the FW (proteins, carbohydrates and lipids) has biogas production potential (Lopez et al., 2016). The technical parameters related to methane yield and dewatering are referred from relevant published literature. External water is added to adjust the solid content to 8-10\% as a typical wet anaerobic digestion (Lv et al., 2017).

Biogas consists of a mixture of methane and carbon dioxide. The theoretical methane potential of Chinese FW, calculated by the Buswell equation (see Appendix Eq. (A.1)) is $580 \mathrm{~m}^{3} \mathrm{CH}_{4} / \mathrm{t}$ VS. The measured methane production of Chinese FW (as mono-digested) based on the literature (Appendix Table A.1) is in the range of $372-455 \mathrm{~m}^{3} / \mathrm{t}$ VS, with an average yield of $407 \mathrm{~m}^{3} / \mathrm{t}$ VS. This value suggests that a $70 \%$ (with a standard deviation of 5\%) utilization of the theoretical methane potential is realistic in a continuous-flow reactor. Along with biogas production, a large amount of digestate is produced. The solid fraction of digestate can be used for soil amendment after composting and aging. 


\subsection{Biomethane production}

Biomethane is produced from biogas after the removal of the $\mathrm{CO}_{2}$ content through biogas upgrading (Pöschl et al., 2010).. A range of upgrading technologies are available (pressure swing adsorption, water scrubbing, membrane separation etc.). Energy consumption is a significant and major factor in selecting technologies. Water scrubbing was chosen in the present study because it has the lowest energy consumption as described by both Hahn et al., (2014) and Patterson et al., (2011) (0.20-0.43 kWh/ $\mathrm{Nm}^{3}$; gas leaking rate of $\left.0.5-2 \%\right)$. The pure $\mathrm{CO}_{2}$ after biogas upgrading could be sold for industrial applications (Esposite et al., 2019; Ryckebosch et al., 2011) or applied in construction material production (Wang et al., 2018).

\subsection{Bioethanol production}

The technical route for bioethanol production can be described as saccharification, solid liquid separation, fermentation and distillation (Sun et al., 2013). Bioethanol is obtained after converting the carbohydrates in FW into sugars (saccharification by means of glucoamylase) and subsequently converting the sugars into bioethanol (fermentation by Saccharomyces cerevisiae) (see Appendix B for details). The solid content is adjusted to $10-15 \%$ total solid (TS) by adding water to obtain the maximum efficiency of saccharification (Ma et al., 2016; Tang et al., 2008); in our work, we used an average of $12 \%$ of TS with an addition of $50 \mathrm{t}$ of water per $100 \mathrm{t}$ of FW. The efficiencies are $62-100 \%$ (of carbohydrate) for saccharification, 66-89\% (of glucose) for solid-liquid separation, and 72-100\% (of glucose) for glucose fermentation to ethanol. Bioethanol can be separated from the liquid mixture via distillation. Data on distillation was adopted from (Balat, 2011). Bioethanol is distilled off as a product; in our work, we used a distillation efficiency of $96.5 \%$ (of bioethanol) (Ebner et al., 2014).

\subsection{Biodiesel production}

The technical route for biodiesel production can be described as two main sub-processes: transesterification and washing (Wen et al., 2016). Biodiesel, which comprises mono-alkyl esters of fatty acids, is produced from the lipid content of FW through transesterification with methanol in the presence of lipase converted into triglyceride (lipid from FW), methyl esters (biodiesel) and glycerol (by-product) (Heimann, 2016). Details are provided in Appendix C. After the transesterification, biodiesel is purified and washed with water to remove residues. The biodiesel production constitutes $81-100 \%$ of the lipids; in our work, we used an average value of $91.5 \%$. 
Table 2 Technical data used in the modeling based on the literature. The numbers in brackets reflect the number of referenced papers; the absence of a bracket indicates that only one paper is referenced.

\begin{tabular}{|c|c|c|c|c|}
\hline Process & Parameter & Value & Unit & Reference \\
\hline \multirow[t]{2}{*}{ Centrifugation } & Efficiency for lipids & 83 & $\%, \mathrm{w}$ of lipids & Anaerobic digestion plant in Jiangsu, China, 2017 \\
\hline & Energy consumption & 4.5 & $\mathrm{kWh} / \mathrm{t} \mathrm{TWW}$ & (Jin et al., 2015) \\
\hline \multirow[t]{3}{*}{ Transesterification } & Biodiesel productivity & $91.6 \pm 6.1(7)^{\mathrm{a}}$ & $\%$, w of lipids & $\begin{array}{l}\text { (Yang et al., 2012)(Torres et al., 2013)(Karmee et al., } \\
\text { 2015)(Sakuragi et al., 2016)(Wen et al., 2016)(Karmee, } \\
\text { 2016)(Wang et al., 2017) }\end{array}$ \\
\hline & Lipase consumption & 40 & kg/t lipids & (Jin et al., 2015) \\
\hline & Energy consumption & 137 & $\mathrm{kWh} / \mathrm{t}$ TWW & (Jian et al., 2010) \\
\hline \multirow[t]{7}{*}{ Saccharification and fermentation } & Saccharification Efficiency & $84.0 \pm 16.7(4)$ & $\%$, w of carbohydrate & (Tao et al., 2005)(Tang et al., 2008)(Koike et al., \\
\hline & Solid-liquid separation Efficiency & $85.0 \pm 10.8(5)$ & $\%$, w of glucose & 2009)(Yan et al., 2013)(C. Wu et al., 2015)(Uçkun \\
\hline & Bioethanol fermentation Efficiency & $90.4 \pm 9.1(7)$ & $\%$, w of glucose & Kiran et al., 2015)(Ma et al., 2016) \\
\hline & Glucoamylase consumption & 2.4 & kg/t carbohydrate & (Ma et al., 2016) \\
\hline & Energy consumption & 66 & $\mathrm{kWh} / \mathrm{t}$ TWW & (L. J. Wu et al., 2015) \\
\hline & Ethanol distillation Efficiency & 96.5 & $\%$, w of bioethanol & (Ebner et al., 2014) \\
\hline & Energy consumption of distillation & 420 & $\mathrm{kWh} / \mathrm{t} \mathrm{EtOH}$ & (Quiroz-Arita et al., 2017) \\
\hline \multirow[t]{3}{*}{ Anaerobic digestion } & Methane yield & $70 \% \pm 5$ (6) of theoretical value & $\mathrm{mL} / \mathrm{g}-\mathrm{VS}$ & $\begin{array}{l}\text { (Zhang et al., 2011) (Zhang et al., 2012) (Zhang et al., } \\
\text { 2013) (Li et al., 2016) }\end{array}$ \\
\hline & Biogas leaking & 1.5 & $\%$, v of biogas & (Jensen et al., 2016) \\
\hline & Energy consumption & 26 & $\mathrm{kWh} / \mathrm{t} \mathrm{TWW}$ & (Jin et al., 2015) \\
\hline \multirow[t]{2}{*}{ Biogas upgrading } & Biogas leaking & 1.5 & $\%$, v of biogas & (Hahn et al., 2014) \\
\hline & Energy consumption & 0.30 & $\mathrm{kWh} / \mathrm{m}^{3} \mathrm{CH}_{4}$ & (Patterson et al., 2011) (Sin et al., 2016) \\
\hline \multirow[t]{3}{*}{ Digestate dewatering } & C (to liquid fraction) & 20.8 & $\%$ & (Stoknes et al., 2016) \\
\hline & $\mathrm{K}$ (to liquid fraction) & 73.9 & $\%$ & (Stoknes et al., 2016) \\
\hline & $\mathrm{N}$ (to liquid fraction) & 79.3 & $\%$ & (Stoknes et al., 2016) \\
\hline
\end{tabular}




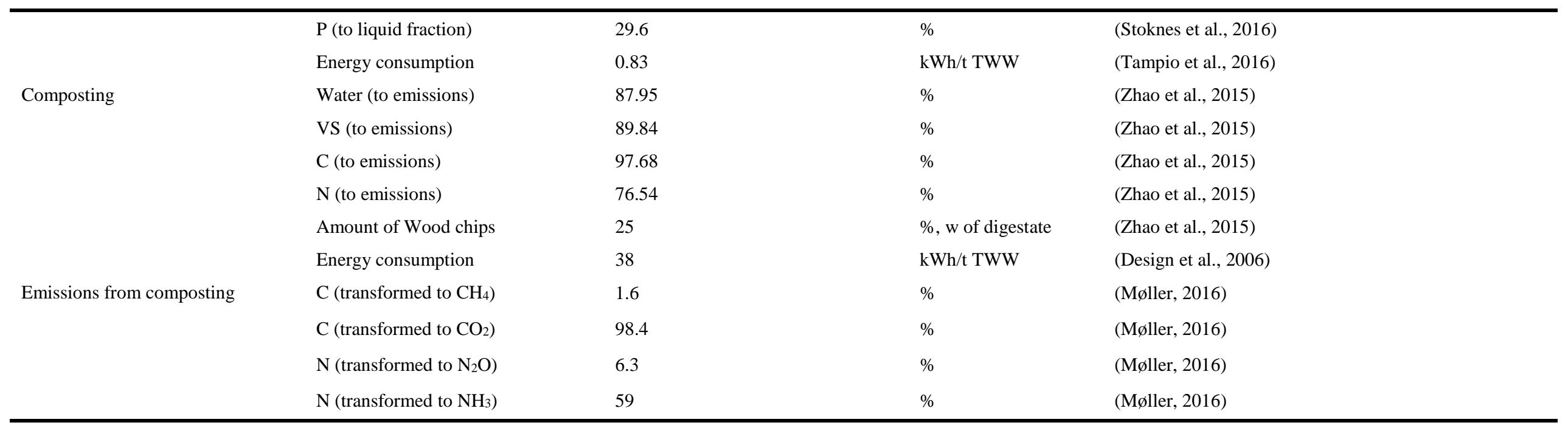

${ }^{a}$ When more than one source of data was found, value was presented as average \pm standard deviation.

TWW: total wet weight; EtOH: ethanol; VS: volatile solid; w: weight 


\subsection{Material flow modeling}

The material and substance flows of the alternative biorefinery scenarios were modeled with the EASETECH model (Environmental Assessment System for Environmental TECHnologies, v2.4.5) (Clavereul et al., 2014) while the results were fed to the software STAN for graphical presentation (subSTance flow ANalysis, 2.6) (Cencic and Rechberger, 2008a).

EASETECH, a waste-LCA model focusing on the management of complex waste streams (Christensen et al., 2015), can be used to handle the flow of complex heterogeneous fractions in various bioprocess systems. Clavreul et al., (2014) described the framework and the calculation structure in detail. STAN is used to analyze material flow (Cencic and Rechberger, 2008b).

The modeling of the material and substance flows involved more than 30 modules in EASETECH. The modules represent centrifugation, transesterification, saccharification, bioethanol fermentation, anaerobic digestion, biogas leaking from the digester, biogas upgrading, digestate dewatering, composting, and emissions from composting. Transport was not included. The scenarios established in EASETECH are shown in Appendix D.

\subsection{Scenarios}

The five alternative scenarios for biorefining Chinese FW are described below. The material and nutrient flow modeling assumed that all scenarios received $100 \mathrm{t}$ of wet Chinese FW. The establishment of scenarios are referred from various previously studies. Cesaro and Belgiorno, (2015), Miezah et al., (2017) and Tan et al., (2014) made an effort to produce biogas as well as bioethanol from FW. Hao et al., (2015), Li et al., (2016b) and Wen et al., (2016) provided examples of converting FW into biogas and biodiesel. S. Karmee and Lin, (2014), Zhang et al., (2016) and Sawatdeenarunat et al., (2016) also explained ways to convert FW into various biofuels.

The parameters listed in Table 2 are applied in all scenarios. The reaction efficiencies are specific: the efficiency of transesterification reaction relates to the amount of lipids,.while for the bioethanol production processes the parameters relate to the amount of carbohydrates or glucose.

\subsubsection{Scenario SO - Biogas as the targeting product (Anaerobic digestion + composting)}

S0 is the baseline scenario. The separately collected FW is sent to an anaerobic digester to produce biogas. The digestate is split into a solid fraction (SF) and a liquid fraction (LF) via dewatering. The SF is subject to composting with wood 
chips in an open windrow and the compost can be used, for example, as a biofertilizer. Wood chips are used as structural material to improve the aeration needed for the aerobic process (Bernstad and la Cour Jansen, 2011) (Hayes et al., 2016). The LF most likely needs treatment prior to discharge or use. The main products from Scenario S0 are biogas, compost and liquid residue.

2.8.2 Scenario S1 - Biomethane as the targeting product (Anaerobic digestion + biogas upgrading + composting)

Biogas produced as Scenario S0 is upgraded to biomethane through the removal of $\mathrm{CO}_{2}$ and hydrogen sulfide. The digestate is treated in the same way as that described in Scenario S0. The main products from Scenario S1 are biomethane, $\mathrm{CO}_{2}$, compost and liquid residue.

2.8.3 Scenario S2 - Bioethanol as the targeting product (Saccharification and fermentation + anaerobic digestion + composting)

Bioethanol is produced by fermentation on the liquid flow after water addition and separation of solids. The bioethanol is distilled off and the residues are subject to anaerobic digestion. The SF of the residue is composted as described in Scenario S0. The main products are bioethanol, biogas, compost and liquid residues.

2.8.4 Scenario S3 - Biodiesel as the targeting product (Transesterification + anaerobic digestion + composting)

Biodiesel is produced on the lipid fraction of the FW separated by centrifugation. After transesterification with methanol, washing with water and dehydration, three products are obtained: biodiesel, crude glycerol and asphalt. All of the residues (including the wastewater from the washing system) are anaerobically digested to produce biogas. The main products are biodiesel, bioasphalt, crude glycerol, biogas, liquid residue and compost.

2.8.5 Scenario S4 - Biodiesel and bioethanol as the targeting product (Transesterification + saccharification and fermentation + anaerobic digestion + composting)

Biodiesel is produced on the lipid fraction of FW separated by centrifugation as described in Scenario S3, while the remaining fraction is used for bioethanol production as described in Scenario S2. The residue of ethanol fermentation is subjected to anaerobic digestion for biogas production followed by composting of the solid residue. The products are biodiesel, crude glycerol, bioasphalt, bioethanol, biogas, compost and liquid residue.

\section{Results and Discussion}

The study addresses 100 t of wet Chinese FW; this could be the amount that a full 
scale plant process each day. The FW is collected from restaurants and hotels and transported to the biorefinery plant, where impurities are removed manually prior to the actual bioerefining (Jin et al., 2015). The products produced maybe used locally or sold on the market. The current study focuses on the technological alternatives and exclude activities before and after the biorefinery.

Table 1 shows that FW composition is rather uncertain. The large standard deviation indicates that FW composition varies significantly, likely due to differences in the source, collection method, and maybe time of the year. In particular, the carbohydrate content varies significantly and future research should address this issue.

\subsection{Material flow analysis}

Figure 1 shows the estimated material flows originating from $100 \mathrm{t}$ of wet Chinese FW subject to treatment in the five alternative biorefinery scenarios. The $100 \mathrm{t}$ Chinese FW contains $4.6 \mathrm{t}$ of lipids in dry matter (DM), $10.5 \mathrm{t}$ of carbohydrates (DM) and 84.9 t other components, including other organic compounds (5.5 t DM) and water (79.4 t). Water (50 t), chemicals, wood chips and other supporting materials are shown as well. The flow diagrams show the complexity of the biorefinery scenarios and the variety of outputs and emissions. The amount of external water is the same in all scenarios. The small addition of enzymes/additives is not included in the mass flows. The consistency of the input materials ensures the comparability of the alternative scenarios.

Though the five scenarios generate different products of different quantities, a high amount of liquid residue is produced (124-126 t) in all scenarios. The numerical values for the flows in all scenario can be found in Table 3.

The comprehensive analysis of these five alternative flow diagrams shows that the biorefining of $100 \mathrm{t}$ of Chinese FW can produce around 3.8 $\pm 1.6 \mathrm{t}$ ethanol, $3.0 \pm 0.2 \mathrm{t}$ biodiesel and from $6.3 \pm 1.7$ to15.8 $\pm 1.1 \mathrm{t}$ of biogas; a low amount of biogas is produced when bioethanol and biodiesel are produced and a high amount is produced when only biogas is produced. The upgrading of $15.5 \pm 1.1 \mathrm{t}$ biogas produces $5.2 \pm 0.4 \mathrm{t}$ biomethane $\left(>98 \% \mathrm{CH}_{4}\right)$. When biodiesel is produced, $0.9 \pm 0.1 \mathrm{t}$ of byproducts, including bio asphalt and crude glycerol, are also produced.

In the baseline scenario (S0), 18\% of the input FW material appears as bioproducts (biogas and compost), $7 \%$ is emitted to the surroundings, and $75 \%$ appears in the wastewater. After biogas upgrading in S1, only $7.2 \%$ of the input FW material is transferred to bioproducts (biomethane and compost). If the removed $\mathrm{CO}_{2}$ is considered a product (Esposite et al., 2019; Ryckebosch et al., 2011) the transformation value to bioproduct is $18 \%$. 
According to the material flow analysis, the ratios of FW transferred into bioethanol and biogas in S2 are 3.8\% and 11.6\%, respectively. This is a moderate estimation and similar to previously reported results from the same technical route (Tang et al., 2008). The production of bioethanol (S2, S4) entails additional $\mathrm{CO}_{2}$ emissions during the fermentation process. Thus, the emissions in S2 and S4 are higher than in the baseline scenario.

In the biodiesel scenario (S3), about $14 \%$ of input FW material ends up in biogas, biodiesel and its by-products. The material flows are comparable to those with liquid fraction for biodiesel and biogas production, and the by-products from the lipids are also verified in other studies (Wen et al., 2016). However, given the complicated routes for FW biorefinery, the overall transfer coefficient is different from that reported in a similar biorefinery system (Jin et al., 2015). The differences are mainly attributed to the different FW composition and the different lipid separation efficiency in the biodiesel technology. This implies that not only the biorefinery route play important roles in the FW material flows, but also the specific parameters do. A comprehensive analysis of parameters from broad sources is desired in future research. 


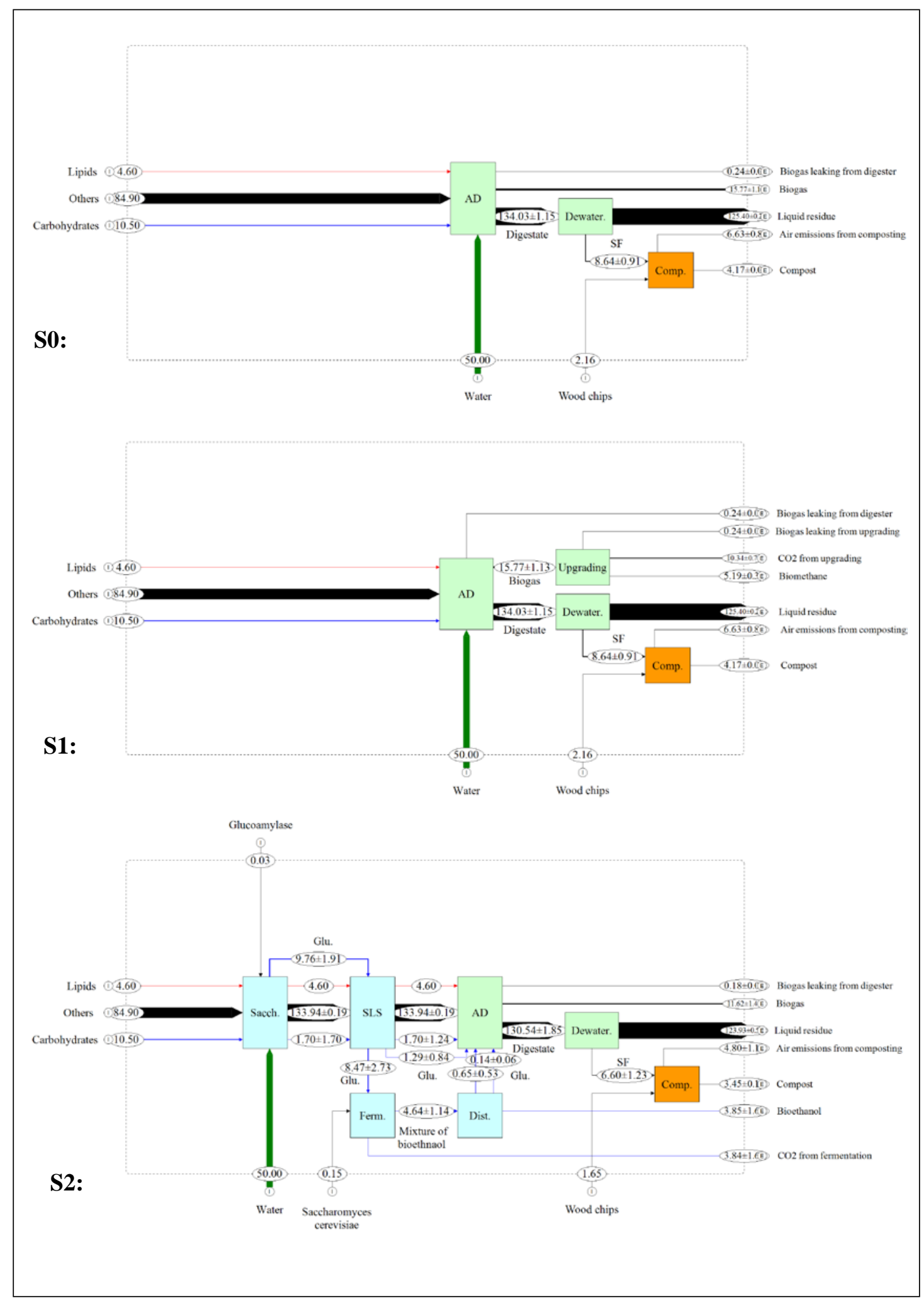




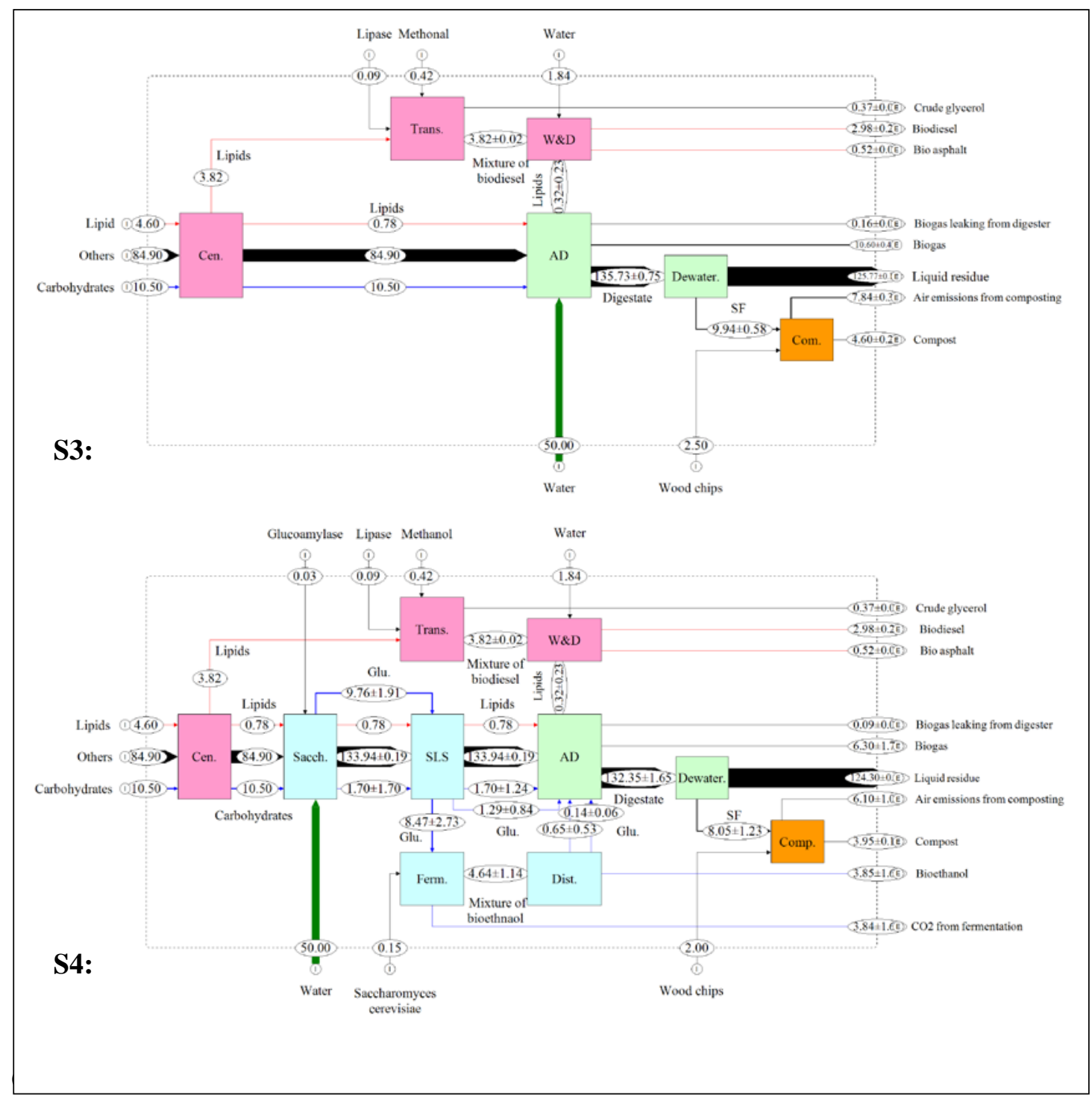

Dist: distillation; AD: anaerobic digestion; Trans.: transesterification; W\&D: washing and dehydration; Dewater.: dewatering; Comp.: composting; Glu.: glucose; SF: solid fraction

Scenario SO - Biogas (Anaerobic digestion + composting)

Scenario S1- Biomethane (Anaerobic digestion + biogas upgrading + composting)

Scenario S2 - Bioethanol (Saccharification and fermentation + anaerobic digestion

+ composting)

Scenario S3 - Biodiesel (Transesterification + anaerobic digestion + composting)

Scenario S4 - Bioethanol + biodiesel (Transesterification + saccharification and fermentation + anaerobic digestion + composting)

Figure 1 Material flows on five alternative biorefinery scenarios for Chinese food waste (based on $100 \mathrm{t}$ wet weight of food waste)

The high water content of Chinese FW suggests that the costs of collection and transportation may be relatively high because of the low content of useful organic 
solid material. However, in terms of the biorefinery processing of FW, the high water content is beneficial and reduces the demand for additional water for optimal bioprocessing (such as the bioprocesses related to carbohydrate saccharification). Nevertheless, all biorefinery scenarios deliver a liquid residue as a result of the low solid content in the biorefining reactors; in terms of weight the liquid residue exceeds the amount of FW processed (+25\%). The liquid residue contains $2.5-5.0 \mathrm{~kg} / \mathrm{m}^{3}$ of C, $3.3-3.4 \mathrm{~kg} / \mathrm{m}^{3}$ of $\mathrm{N}, 0.18 \mathrm{~kg} / \mathrm{m}^{3}$ of $\mathrm{P}$, and $1.3 \mathrm{~kg} / \mathrm{m}^{3}$ of $\mathrm{K}$. This LF must be managed further.

\subsection{Substance flow analysis (C, $N, P, K)$}

Figure 2 shows the carbon flows through the five biorefinery scenarios. The $100 \mathrm{t}$ of Chinese FW contains 9.96 t C, 0.53 t N, 0.08 t P and 0.22 t K).

The carbon flow diagrams show that $40-75 \%$ of the carbon (increasing from S1 to S4) ends up in the bioproducts, namely, biogas, biomethane, bioethanol and biodiesel; only small amounts end up in the compost. Most of the carbon (1 t) in the compost originates from the wood chips added as a bulking agent to the composting process. This result suggests that around $75 \%$ of the carbon in the FW is found in the bioproducts and that about $22 \%$ is lost through air emissions (primarily during composting) and in the liquid residue (3\%).

As the nutrients, namely, nitrogen $(\mathrm{N})$, phosphorus $(\mathrm{P})$ and potassium $(\mathrm{K})$ are absent in the carbohydrates and lipids utilized in bioethanol or biodiesel production, their fate in biorefinery is almost the same in all five scenarios. Figure 3 shows the flows of nutrients $(0.53 \mathrm{t} \mathrm{N}, 0.08 \mathrm{t} \mathrm{P}$ and $0.22 \mathrm{t} \mathrm{K})$ present in the $100 \mathrm{t} \mathrm{FW}$, as determined by the transfer coefficients listed in Table 2. Given the lack of data, we neglect the possibility of a small amount of $\mathrm{N}$ transferring to the biogas. The fate of the nutrients downstream the digester is controlled by the separation of residue into a liquid and a solid flow and for nitrogen also on the loss during composting. Figure 3 reveals that $79 \%$ of the initial $\mathrm{N}$ from $\mathrm{FW}$ ends up in the liquid residue, $6 \%$ is found in the compost and about $15 \%$ is lost during composting. From the substance flow perspective, $25 \%$ of $\mathrm{P}$ and $73 \%$ of $\mathrm{K}$ end up in the liquid residue, while the compost contains $6 \% \mathrm{~N}, 75 \% \mathrm{P}$ and $27 \% \mathrm{~K}$ from FW. This shows that all biorefinery scenarios preserve the nutrients well. The air emissions of $\mathrm{P}$ and $\mathrm{K}$ are insignificant.

We must note that nutrient source is essential during ethanol fermentation as it provides a balanced nutrient source for bacterial growth metabolisms. Moreover, with the $\mathrm{C} / \mathrm{N}$ ratio less than $30, \mathrm{FW}$ can be considered as a suitable biomedium for its ethanol fermentation without additional nutrient supply. This idea is supported by many previous studies (Ma et al., 2009; Uçkun Kiran et al., 2015; Uncu and Cekmecelioglu, 2011). All of these nutrients flow to the next technical stage (anaerobic digestion). 


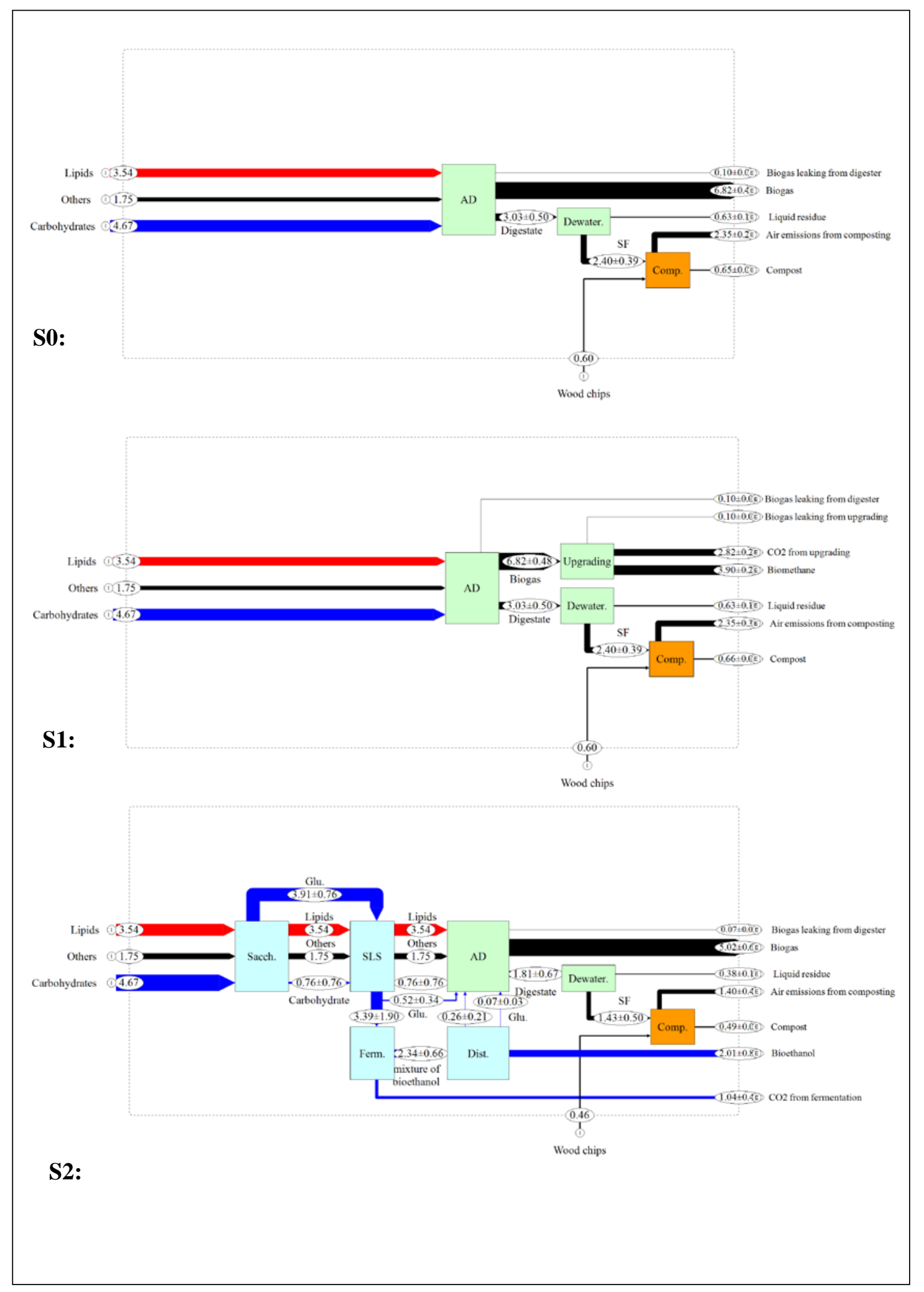




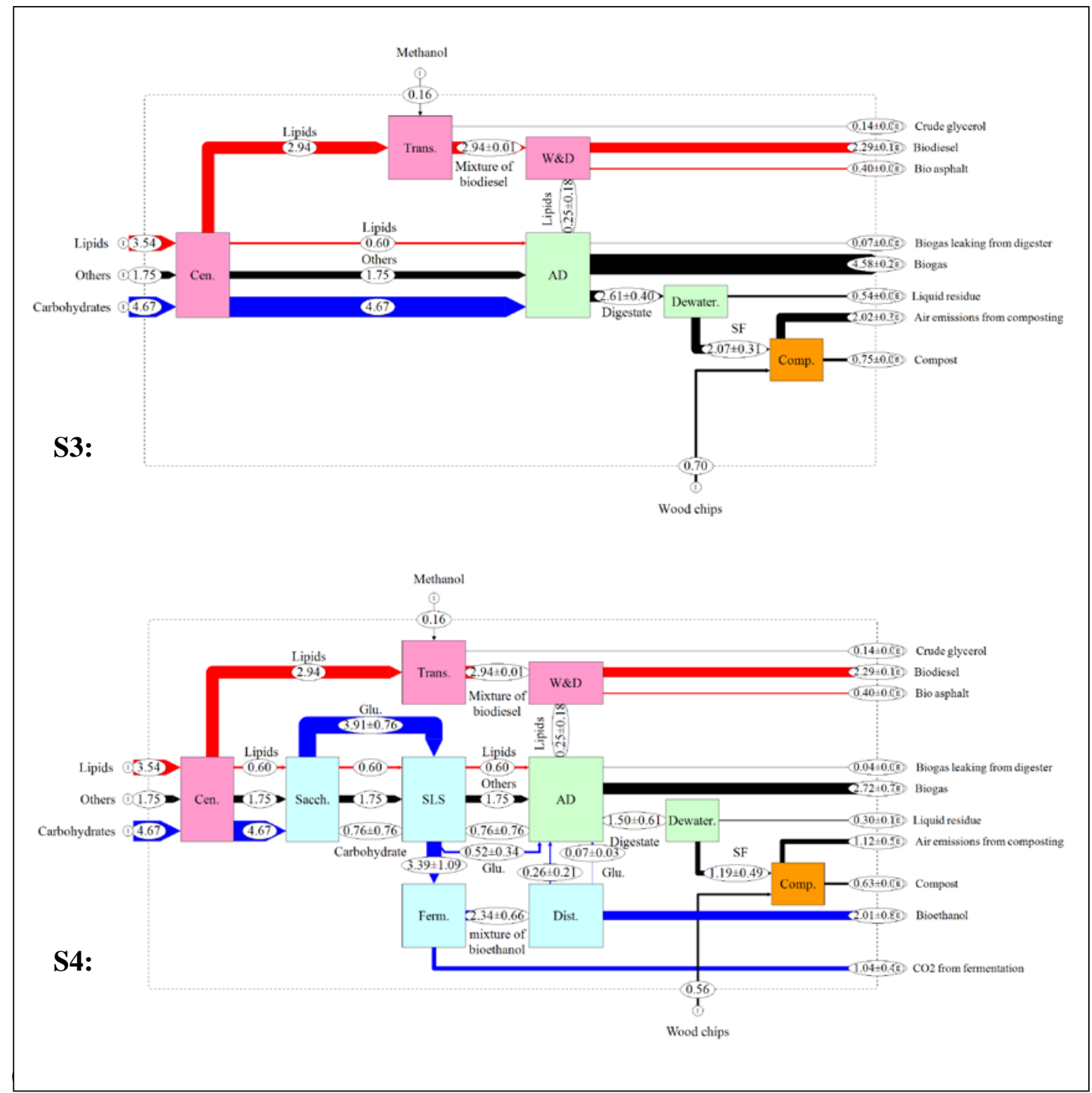

Dist: distillation; AD: anaerobic digestion; Trans.: transesterification; W\&D: washing and dehydration; Dewater.: dewatering; Comp.: composting; Glu.: glucose; SF: solid fraction

Scenario SO - Biogas (Anaerobic digestion + composting)

Scenario S1 - Biomethane (Anaerobic digestion + biogas upgrading + composting)

Scenario S2 - Bioethanol (Saccharification and fermentation + anaerobic digestion + composting)

Scenario S3 - Biodiesel (Transesterification + anaerobic digestion + composting)

Scenario S4 - Bioethanol + biodiesel (Transesterification + saccharification and fermentation + anaerobic digestion + composting)

Figure 2 Carbon flow of the five alternative biorefinery scenarios for Chinese food waste (based on $100 \mathrm{t}$ wet weight of food waste containing $9.95 \mathrm{t}$ ) 


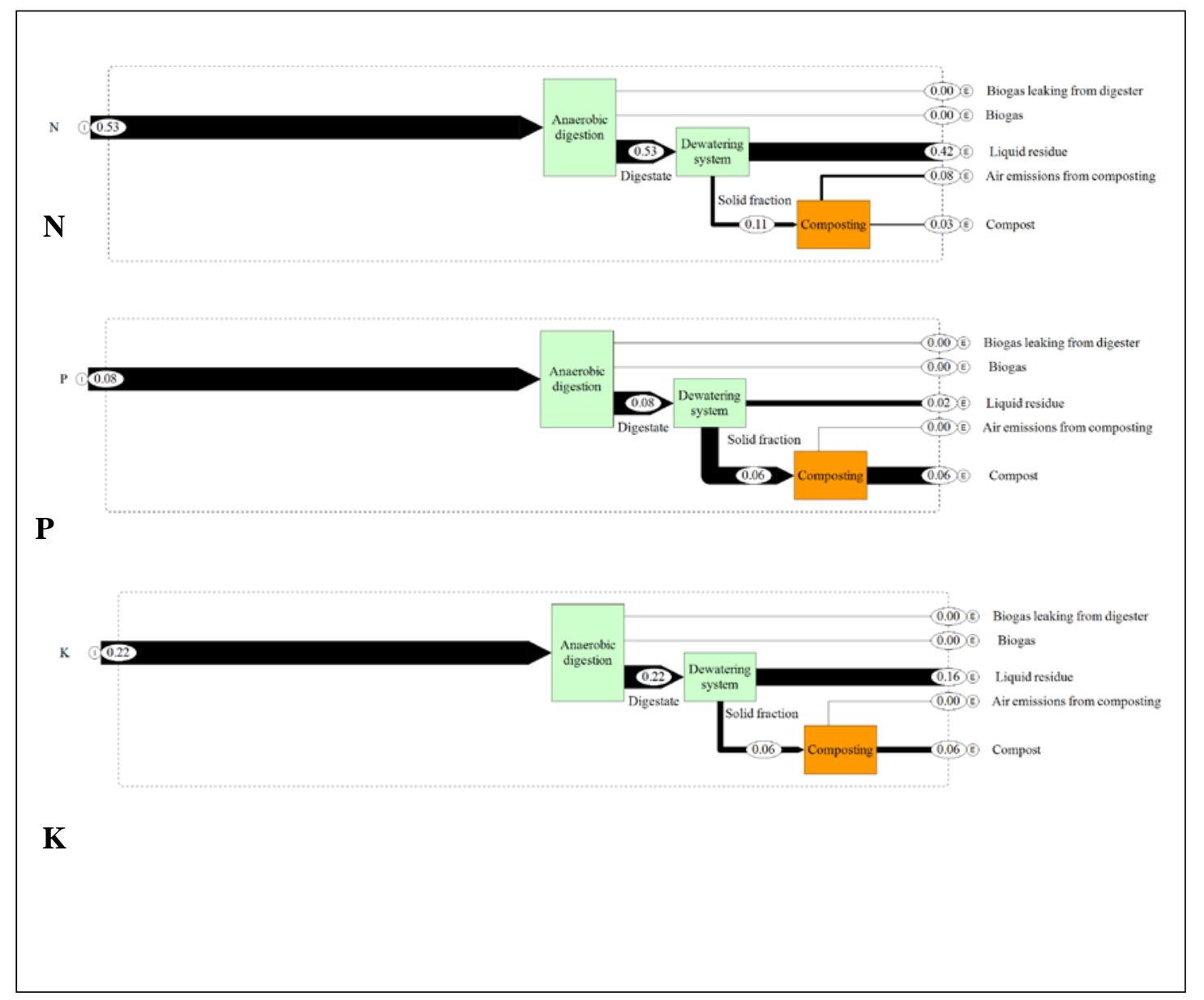

Figure $3 \mathrm{~N} / \mathrm{P} / \mathrm{K}$ flow of the five alternative biorefinery scenarios for Chinese food waste (based on $100 \mathrm{t}$ wet weight of food waste containing $0.53 \mathrm{t} \mathrm{N}, 0.08 \mathrm{t} \mathrm{P}$, and 0.22 t K)

\subsection{Material inventory}

Table 3 shows the inventory of the five biorefinery scenarios in terms of all inputs and outputs when treating $100 \mathrm{t}$ of Chinese FW. 
Table 3 Inventory of the five biorefinery scenarios for $100 \mathrm{t}$ of Chinese FW.

\begin{tabular}{|c|c|c|c|c|c|c|c|}
\hline \multirow{2}{*}{ Inputs } & & \multirow{2}{*}{ Unit } & \multicolumn{5}{|c|}{ Total amount } \\
\hline & & & So & S1 & S2 & S3 & S4 \\
\hline Waste & Food waste & $\mathrm{t}$ & 100 & 100 & 100 & 100 & 100 \\
\hline \multirow[t]{6}{*}{ Additive chemicals } & Water & $\mathrm{t}$ & 50 & 50 & 50 & 51.8 & 51.8 \\
\hline & Wood chips & $\mathrm{t}$ & 2.16 & 2.16 & 1.65 & 2.5 & 2 \\
\hline & Methanol & $\mathrm{t}$ & 0 & 0 & 0 & 0.42 & 0.42 \\
\hline & Glucoamylase & $\mathrm{t}$ & 0 & 0 & 0.027 & 0 & 0.027 \\
\hline & Saccharomyces cerevisiae & $\mathrm{t}$ & 0 & 0 & 0.15 & 0 & 0.15 \\
\hline & Lipase & $\mathrm{t}$ & 0 & 0 & 0 & 0.092 & 0.092 \\
\hline \multirow[t]{8}{*}{ Energy use } & Centrifugation & $\mathrm{kWh}$ & 0 & 0 & 0 & 0.45 & 0.45 \\
\hline & Transesterification & kWh & 0 & 0 & 0 & 0.58 & 0.58 \\
\hline & Saccharification \& fermentation & $\mathrm{kWh}$ & 0 & 0 & 9.90 & 0 & 9.65 \\
\hline & Ethanol distillation & $\mathrm{kWh}$ & 0 & 0 & 1.57 & 0 & 1.57 \\
\hline & Anaerobic digestion & $\mathrm{kWh}$ & 3.90 & 3.90 & 3.71 & 3.86 & 3.66 \\
\hline & Biogas upgrading & $\mathrm{kWh}$ & 0 & 2.21 & 0 & 0 & 0 \\
\hline & Digestate dewatering & $\mathrm{kWh}$ & 0.11 & 0.11 & 0.11 & 0.11 & 0.11 \\
\hline & Composting & $\mathrm{kWh}$ & 0.46 & 0.46 & 0.34 & 0.51 & 0.40 \\
\hline Outputs & & Unit & So & S1 & S2 & S3 & S4 \\
\hline \multirow[t]{4}{*}{ Emissions } & $\mathrm{CH}_{4} *$ & $\mathrm{t}$ & $0.13 \pm 0.00$ & $0.21 \pm 0.00$ & $0.09 \pm 0.02$ & $0.10 \pm 0.00$ & $0.06 \pm 0.02$ \\
\hline & $\mathrm{CO}_{2} *$ & $\mathrm{t}$ & $8.63 \pm 1.34$ & $8.79 \pm 1.37$ & $5.15 \pm 1.79$ & $7.40 \pm 1.09$ & $4.13 \pm 1.68$ \\
\hline & $\mathrm{N}_{2} \mathrm{O}$ & $\mathrm{t}$ & 8.3E-03 & 8.3E-03 & 8.3E-03 & 8.3E-03 & 8.3E-03 \\
\hline & $\mathrm{NH}_{3}$ & $\mathrm{t}$ & 6.0E-02 & 6.0E-02 & 6.0E-02 & 6.0E-02 & 6.0E-02 \\
\hline \multirow[t]{2}{*}{ Products } & Biogas & $\mathrm{t}$ & $15.77 \pm 1.13$ & 0 & $11.62 \pm 1.47$ & $10.60 \pm 0.48$ & $6.30 \pm 1.72$ \\
\hline & Biomethane & $\mathrm{t}$ & 0 & $5.19 \pm 0.37$ & 0 & 0 & 0 \\
\hline
\end{tabular}




\begin{tabular}{|c|c|c|c|c|c|c|c|}
\hline & Bioethanol & $\mathrm{t}$ & 0 & 0 & $3.85 \pm 1.60$ & 0 & $3.85 \pm 1.60$ \\
\hline & Biodiesel & $\mathrm{t}$ & 0 & 0 & 0 & $2.99 \pm 0.20$ & $2.99 \pm 0.20$ \\
\hline & Bio asphalt & $\mathrm{t}$ & 0 & 0 & 0 & $0.53 \pm 0.04$ & $0.53 \pm 0.04$ \\
\hline & Crude glycerol & $\mathrm{t}$ & 0 & 0 & 0 & $0.37 \pm 0.02$ & $0.37 \pm 0.02$ \\
\hline \multirow[t]{3}{*}{ Residues } & Stored $\mathrm{CO}_{2}$ from biogas upgrading & $\mathrm{t}$ & 0 & $10.34 \pm 0.74$ & 0 & 0 & 0 \\
\hline & $\mathrm{CO}_{2}$ from bioethanol production & $\mathrm{t}$ & 0 & 0 & $3.84 \pm 1.60$ & 0 & $3.84 \pm 1.60$ \\
\hline & Liquid residue & $\mathrm{t}$ & $125.4 \pm 0.2$ & $125.4 \pm 0.2$ & $123.93 \pm 0.55$ & $125.77 \pm 0.15$ & $124.3 \pm 0.50$ \\
\hline
\end{tabular}

Scenario S0-Biogas; Scenario S1: Biomethane; Scenario S2: Bioethanol; Scenario S3: Biodiesel; Scenario S4: Bioethanol+biodiesel 
Water and wood chips are added in all scenarios. Glucoamylase and S. cerevisiae are the essential additives in bioethanol production while methanol and lipase are needed in biodiesel production.

Energy consumption is listed for each technological process. Centrifugation, transesterification, saccharification and fermentation, ethanol distillation, anaerobic digestion, biogas upgrading, digestate dewatering and composting are the key technological processes in the systems. The highest energy consumption takes place in the bioethanol production processes (saccharification and fermentation) for heating, followed by anaerobic digestion with heating. We note that saccharification and bioethanol-fermentation involve full FW flow, and that the transesterification for biodiesel production involves only the lipid flow obtained after the separation of oil from the FW. The energy consumption for the five scenarios is estimated to be in the range of $45-165 \mathrm{kWh} / \mathrm{t} \mathrm{FW}$.

The main emissions are $\mathrm{CH}_{4}, \mathrm{CO}_{2}, \mathrm{~N}_{2} \mathrm{O}$ and $\mathrm{NH}_{3}$. $\mathrm{CH}_{4}$ leaks from the anaerobic digester and is emitted during the upgrading process and composting due to unavoidable anaerobic pockets in the windrow. $\mathrm{CO}_{2}$ leaks from anaerobic digesters and is emitted from ethanol fermentation, biogas upgrading and the composting process. $\mathrm{N}_{2} \mathrm{O}$ and $\mathrm{NH}_{3}$ are emitted only from the composting process. $\mathrm{CO}_{2}$ is the largest fraction of (gas) emissions in the range of $97-99 \%$ followed by $\mathrm{CH}_{4}$ in the range of $0.7-2.3 \%$.

Biomethane, bioethanol and biodiesel can be used as substitutes for fossil fuel (compressed natural gas, petrol, diesel, etc,.) while crude glycerol and bioasphalt can be used as biochemicals. $\mathrm{CO}_{2}$ from biogas upgrading can be stored and also treated as a supply for the chemical industry. Nevertheless, the liquid residue, produced in large quantities in all scenarios, constitutes a separate management issue that presents as a wastewater problem or a potentially as liquid fertilizer.

In terms of output diversity and amounts of products, scenario S4 seems to be the most promising scenario in our study. Though our study provides consistent technical engineering platforms for alternative biorefineries for FW, specific assessments in technical, economic and environmental terms must be carefully conducted before recommending any alternative for treating $\mathrm{FW}$ in industrial practice.

Future efforts should address other technical routes and bioproducts to expand the biorefinery platform related to material balance. Researchers are encouraged to take the full-chain, material balance and transformation, bioproducts' utilization and geographical characteristics into consideration in their future work to improve this platform. Furthermore, assessment in terms of technical feasibility, economic and environmental should be conducted to support the management of alternative FW 
biorefinery systems.

\section{Conclusion}

This study provides a systematic modeling of material and substance flows of five alternative scenarios for treating Chinese FW on the basis of a biorefinery concept that produces valuable bioproducts (i.e., biogas, biomethane, biodiesel and bioethanol). All scenarios produce bioproducts in the range 7-18 t out of $100 \mathrm{t}$ of wet Chinese FW. The bioethanol production is controlled by the carbohydrate content and biodiesel production is controlled by the lipid content of FW. Anaerobic digestion converts most of the volatile organic solids in the FW. Moreover, the value of products is a crucial consideration when introducing a complex biorefinery concept. The energy consumption of the biorefinery scenarios is estimated, and the results indicate that going from a simple biogas scenario to more complex biorefinery concepts may triple the energy consumption from $45 \mathrm{kWh} / \mathrm{t} \mathrm{FW}$ to 165 $\mathrm{kWh} / \mathrm{t} \mathrm{FW}$. The analysis also reveals that all scenarios result in a high volume (about $125 \%$ in weight of the FW input) of liquid residue that needs further treatment. These outcomes offer a consistent material flow analysis that is useful in comparing alternative biorefinery concepts for managing Chinese FW in terms of technical feasibility, economics and environmental issues.

\section{Acknowledgement}

The present study was supported by the National Key R\&D Program of China (Grant No. 2018YFD1100605), the National Natural Science Foundation of China (Grant No. 51578071), the China Scholarship Council (CSC: No. 201606210401) and Tsinghua University Initiative Scientific Research Program.

\section{Declarations of interest}

None 


\section{Reference}

Balat, M., 2011. Production of bioethanol from lignocellulosic materials via the biochemical pathway: A review. Energy Convers. Manag. 52, 858-875. doi:10.1016/j.enconman.2010.08.013

Bernstad, A., la Cour Jansen, J., 2011. A life cycle approach to the management of household food waste - A Swedish full-scale case study. Waste Manag. 31, 1879-1896. doi:10.1016/j.wasman.2011.02.026

Call, O., Centor, S., Academy, R., Ihstitht, L., 1997. 1. Introduction, in: Practical Handbook of MFA. Cencic, O., Rechberger, H., 2008a. Material flow analysis with software STAN. J. Environ. Eng. Manag. 18, 3-7.

Cencic, O., Rechberger, H., 2008b. Material flow analysis with software STAN. J. Environ. Eng. Manag. 18, 3-7.

Cesaro, A., Belgiorno, V., 2015. Combined biogas and bioethanol production: Opportunities and challenges for industrial application. Energies 8, 8121-8144. doi:10.3390/en8088121

Cherubini, F., 2010. The biorefinery concept : Using biomass instead of oil for producing energy and chemicals. Energy Convers. Manag. 51, 1412-1421. doi:10.1016/j.enconman.2010.01.015

Christensen, T.H., Astrup, T.F., Brogaard, L.K., Bisinella, V., Damgard, A., 2015. Recent Lca Developments in Waste Management. Sardinia 2015, 15th Int. Waste Manag. Landfill Symp. 5-9.

Clavreul, J., Baumeister, H., Christensen, T.H., Damgaard, A., 2014a. An environmental assessment system for environmental technologies. Environ. Model. Softw. 60, 18-30. doi:10.1016/j.envsoft.2014.06.007

Clavreul, J., Baumeister, H., Christensen, T.H., Damgaard, A., 2014b. An environmental assessment system for environmental technologies. Environ. Model. Softw. 60, 18-30. doi:10.1016/j.envsoft.2014.06.007

Coma, M., Martinez-hernandez, E., Abeln, F., Raikova, S., 2017. Organic waste as a sustainable feedstock for platform chemicals. Faraday Discuss. 202, 175-195. doi:10.1039/c7fd00070g

Design, P., Form, D., Pdd, C.-, Board, E., 2006. PROJECT DESIGN DOCUMENT FORM (CDM-SSC- PDD) - Version 03 CDM - Executive Board. Design 1-29.

Ebner, J., Babbitt, C., Winer, M., Hilton, B., Williamson, A., 2014. Life cycle greenhouse gas (GHG) impacts of a novel process for converting food waste to ethanol and co-products. Appl. Energy 130, 86-93. doi:10.1016/j.apenergy.2014.04.099

Esposite, E., Dellamuzia, L., Moretti, U., Fuoco, A., Giorno, L., Jansen, J.C., 2019. Simultaneous production of biomethane and food grade CO2 from biogas: an industrial case study 281-289. doi:10.1039/c8ee02897d

FAO, 2018. Food loss and waste reduction [WWW Document]. Food Agric. Organ. URL www.fao.org/food-loss-and-food-waste/en

Fuldauer, L.I., Parker, B.M., Yaman, R., Borrion, A., 2018. Managing anaerobic digestate from food waste in the urban environment: Evaluating the feasibility from an interdisciplinary perspective. J. Clean. Prod. 185, 929-940. doi:10.1016/j.jclepro.2018.03.045

Gaudino, E.C., Cravotto, G., Manzoli, M., Tabasso, S., 2019. From waste biomass to chemicals and energy via microwave-assisted processes. Green Chem. 1202-1235. doi:10.1039/c8gc03908a 
Hahn, H., Krautkremer, B., Hartmann, K., Wachendorf, M., 2014. Review of concepts for a demand-driven biogas supply for flexible power generation. Renew. Sustain. Energy Rev. 29, 383-393. doi:10.1016/j.rser.2013.08.085

Hao, H.T.N., Karthikeyan, O.P., Heimann, K., 2015. Bio-refining of carbohydrate-rich food waste for biofuels. Energies 8, 6350-6364. doi:10.3390/en8076350

Hayes, A.C., Enongene Ekwe, S., Mervin, S., Jenson, E., 2016. Techno-economic evaluation of a tandem dry batch, garage-style digestion-compost process for remote work camp environments. Waste Manag. 58, 70-80. doi:10.1016/j.wasman.2016.09.043

He, M., Sun, Y., Zou, D., Yuan, H., Zhu, B., Li, X., Pang, Y., 2012. Influence of Temperature on Hydrolysis Acidification of Food Waste. Procedia Environ. Sci. 16, 85-94. doi:10.1016/j.proenv.2012.10.012

Heimann, K., 2016. Recycling of Solid Waste for Biofuels and Bio-chemicals. Springer Nature, Singapore. doi:10.1007/978-981-10-0150-5

IEA, 2012. Bio-based Chemicals Value Added Products from Biorefineries. IEA Bioenergy.

Jensen, M.B., Møller, J., Scheutz, C., 2016. Assessment of a combined dry anaerobic digestion and post-composting treatment facility for source-separated organic household waste, using material and substance flow analysis and life cycle inventory. Waste Manag. doi:10.1016/j.wasman.2017.03.029

Jian, H., Peidong, Z., Youle, W., Xianzheng, Y., 2010. Life cycle assessment of energy consumption and $\mathrm{CO} 2$ emission of biodiesel made from food waste oil (in Chinese). Res. Environ. Sci. 23, 521-526.

Jin, Y., Chen, T., Chen, X., Yu, Z., 2015. Life-cycle assessment of energy consumption and environmental impact of an integrated food waste-based biogas plant. Appl. Energy 151, 227-236. doi:10.1016/j.apenergy.2015.04.058

Karmee, S.K., 2016. Liquid biofuels from food waste: Current trends, prospect and limitation. Renew. Sustain. Energy Rev. 53, 945-953. doi:10.1016/j.rser.2015.09.041

Karmee, S.K., Linardi, D., Lee, J., Lin, C.S.K., 2015. Conversion of lipid from food waste to biodiesel. Waste Manag. 41, 169-173. doi:10.1016/j.wasman.2015.03.025

Koike, Y., An, M.Z., Tang, Y.Q., Syo, T., Osaka, N., Morimura, S., Kida, K., 2009. Production of fuel ethanol and methane from garbage by high-efficiency two-stage fermentation process. J. Biosci. Bioeng. 108, 508-512. doi:10.1016/j.jbiosc.2009.06.007

Laurent, A., Bakas, I., Clavreul, J., Bernstad, A., Niero, M., Gentil, E., Hauschild, M.Z., Christensen, T.H., 2014. Review of LCA studies of solid waste management systems - Part I: Lessons learned and perspectives. Waste Manag. 34, 573-588. doi:10.1016/j.wasman.2013.10.045

Lavelli, V., Proserpio, C., Gallotti, F., 2018. Circular reuse of bio-resources: the role of Pleurotus spp. in the development of functional foods. Food Funct. 9, 1353-1372. doi:10.1039/c7fo01747b

Li, Y., Jin, Y., Li, J., Li, H., Yu, Z., 2016. Effects of thermal pretreatment on the biomethane yield and hydrolysis rate of kitchen waste. Appl. Energy 172, 47-58. doi:10.1016/j.apenergy.2016.03.080

Lin, C.S.K., Pfaltzgraff, L.A., Herrero-Davila, L., Mubofu, E.B., Abderrahim, S., Clark, J.H., Koutinas, A.A., Kopsahelis, N., Stamatelatou, K., Dickson, F., Thankappan, S., Mohamed, Z., Brocklesby, R., Luque, R., 2013. Food waste as a valuable resource for the production of chemicals, materials and fuels. Current situation and global perspective. Energy Environ. Sci. 6, 426. doi:10.1039/c2ee23440h 
Lopez, V.M., De la Cruz, F.B., Barlaz, M.A., 2016. Chemical composition and methane potential of commercial food wastes. Waste Manag. 56, 477-490. doi:10.1016/j.wasman.2016.07.024

Low, S.C., Gan, G.K., Cheong, K.T., 2011. Separation of Methyl Ester from Water in a Wet Neutralization Process. J. Sustain. Energy Environ. 2, 15-19.

Lv, F., Zhang, H., Shao, L., He, P., 2017. Problems of anaerobic digestion process to deal with food waste and its countermeasures through material flow analysis (in Chinese). Environ. Sanit. Eng.

Ma, H., Wang, Q., Zhang, W., Xu, W., Zou, D., 2008. Optimization of the Medium and Process Parameters for Ethanol Production from Kitchen Garbage by Zymomonas Mobilis. Int. J. Green Energy 5, 480-490. doi:10.1080/15435070802498176

Ma, K., Ruan, Z., Shui, Z., Wang, Y., Hu, G., He, M., 2016. Open fermentative production of fuel ethanol from food waste by an acid-tolerant mutant strain of Zymomonas mobilis. Bioresour. Technol. 203, 295-302. doi:10.1016/j.biortech.2015.12.054

Ma, K., Wakisaka, M., Sakai, K., Shirai, Y., 2009. Flocculation characteristics of an isolated mutant flocculent Saccharomyces cerevisiae strain and its application for fuel ethanol production from kitchen refuse. Bioresour. Technol. 100, 2289-2292. doi:10.1016/j.biortech.2008.11.010

Miezah, K., Obiri-Danso, K., Kádár, Z., Heiske, S., Fei-Baffoe, B., Mensah, M., Meyer, A.S., 2017. Municipal Solid Waste Management in a Low Income Economy Through Biogas and Bioethanol Production. Waste and Biomass Valorization 8, 115-127. doi:10.1007/s12649-016-9566-5

Møller, K., 2016. Assessment of Alterative Phosphorus Fertilizers for Organic Farming: Compost and digestates from urban organic wastes 2009.

Patterson, T., Esteves, S., Dinsdale, R., Guwy, A., 2011. An evaluation of the policy and techno-economic factors affecting the potential for biogas upgrading for transport fuel use in the UK. Energy Policy 39, 1806-1816. doi:10.1016/j.enpol.2011.01.017

Pleissner, D., Lam, W.C., Sun, Z., Lin, C.S.K., 2013. Food waste as nutrient source in heterotrophic microalgae cultivation. Bioresour. Technol. 137, 139-146. doi:10.1016/j.biortech.2013.03.088

Pöschl, M., Ward, S., Owende, P., 2010. Evaluation of energy efficiency of various biogas production and utilization pathways. Appl. Energy 87, 3305-3321. doi:10.1016/j.apenergy.2010.05.011

Quiroz-Arita, C., Sheehan, J.J., Bradley, T.H., 2017. Life cycle net energy and greenhouse gas emissions of photosynthetic cyanobacterial biorefineries: Challenges for industrial production of biofuels. Algal Res. 26, 445-452. doi:10.1016/j.algal.2017.06.021

Rudroff, S.F., Chem, G., 2017. From waste to value - direct utilization of limonene from orange peel in a biocatalytic cascade reaction towards chiral carvolactone. Green Chem. 19, 367-371. doi:10.1039/c6gc01138a

Ryckebosch, E., Drouillon, M., Vervaeren, H., 2011. Techniques for transformation of biogas to biomethane. Biomass and Bioenergy 35, 1633-1645. doi:10.1016/j.biombioe.2011.02.033

Sakuragi, K., Li, P., Otaka, M., Makino, H., 2016. Recovery of bio-oil from industrial food waste by liquefied dimethyl ether for biodiesel production. Energies 9, 1-8. doi:10.3390/en9020106

Sawatdeenarunat, C., Nguyen, D., Surendra, K.C., Shrestha, S., Rajendran, K., Oechsner, H., Xie, L., Khanal, S.K., 2016. Anaerobic biorefinery: Current status, challenges, and opportunities. Bioresour. Technol. 215, 304-313. doi:10.1016/j.biortech.2016.03.074

Shen, F., Yuan, H., Pang, Y., Chen, S., Zhu, B., Zou, D., Liu, Y., Ma, J., Yu, L., Li, X., 2013. Performances of anaerobic co-digestion of fruit \& vegetable waste (FVW) and food waste (FW): Single-phase vs. two-phase. Bioresour. Technol. 144, 80-85. doi:10.1016/j.biortech.2013.06.099 
Sherwood, J., Shang, J., 2018. Propylene carbonate and $\gamma$-valerolactone as green solvents enhance $\mathrm{Sn}(\mathrm{IV})$-catalysed hydroxymethylfurfural (HMF) production from bread waste. Green Chem. 20, 2064-2074. doi:10.1039/c8gc00358k

Sin, K., Lo, I.M.C., Chiu, S.L.H., Yan, D.Y.S., 2016. Environmental assessment of food waste valorization in producing biogas for various types of energy use based on LCA approach. Waste Manag. 50, 290-299. doi:10.1016/j.wasman.2016.02.022

Stoknes, K., Scholwin, F., Krzesin’ ski, W., Wojciechowska, E., Jasiń ska, A., 2016. Efficiency of a novel "Food to waste to food" system including anaerobic digestion of food waste and cultivation of vegetables on digestate in a bubble-insulated greenhouse. Waste Manag. 56, 466-476. doi:10.1016/j.wasman.2016.06.027

Sun, Y., Wang, D., Qiao, W., Wang, W., Zhu, T., 2013. Anaerobic co-digestion of municipal biomass wastes and waste activated sludge: Dynamic model and material balances. J. Environ. Sci. (China) 25, 2112-2122. doi:10.1016/S1001-0742(12)60236-8

Tampio, E., Marttinen, S., Rintala, J., 2016. Liquid fertilizer products from anaerobic digestion of food waste: Mass, nutrient and energy balance of four digestate liquid treatment systems. J. Clean. Prod. 125, 22-32. doi:10.1016/j.jclepro.2016.03.127

Tan, L., Sun, Z., Zhang, W., Tang, Y., Morimura, S., Kida, K., 2014. Production of bio-fuel ethanol from distilled grain waste eluted from Chinese spirit making process. Bioprocess Biosyst. Eng. 37, 2031-2038. doi:10.1007/s00449-014-1178-5

Tang, Y.Q., Koike, Y., Liu, K., An, M.Z., Morimura, S., Wu, X.L., Kida, K., 2008. Ethanol production from kitchen waste using the flocculating yeast Saccharomyces cerevisiae strain KF-7. Biomass and Bioenergy 32, 1037-1045. doi:10.1016/j.biombioe.2008.01.027

Tao, F., Miao, J.Y., Shi, G.Y., Zhang, K.C., 2005. Ethanol fermentation by an acid-tolerant Zymomonas mobilis under non-sterilized condition. Process Biochem. 40, 183-187. doi:10.1016/j.procbio.2003.11.054

Torres, E.A., Cerqueira, G.S., M. Ferrer, T., Quintella, C.M., Raboni, M., Torretta, V., Urbini, G., 2013. Recovery of different waste vegetable oils for biodiesel production: A pilot experience in Bahia State, Brazil. Waste Manag. 33, 2670-2674. doi:10.1016/j.wasman.2013.07.030

Uçkun Kiran, E., Trzcinski, A.P., Liu, Y., 2015. Platform chemical production from food wastes using a biorefinery concept. J. Chem. Technol. Biotechnol. 90, 1364-1379. doi:10.1002/jctb.4551

Uncu, O.N., Cekmecelioglu, D., 2011. Cost-effective approach to ethanol production and optimization by response surface methodology. Waste Manag. 31, 636-643. doi:10.1016/j.wasman.2010.12.007

Wang, C., Xie, S., Zhong, M., 2017. Effect of Hydrothermal Pretreatment on Kitchen Waste for Biodiesel Production Using Alkaline Catalyst. Waste and Biomass Valorization 8, 369-377. doi:10.1007/s12649-016-9606-1

Wang, L., Chen, L., Tsang, D.C.W., Li, J., Yeung, T.L.Y., 2018. Green remediation of contaminated sediment by stabilization / solidi fi cation with industrial by-products and CO 2 utilization. Sci. Total Environ. 631-632, 1321-1327. doi:10.1016/j.scitotenv.2018.03.103

Wen, Z., Wang, Y., De Clercq, D., 2016. What is the true value of food waste? A case study of technology integration in urban food waste treatment in Suzhou City, China. J. Clean. Prod. 118, 88-96. doi:10.1016/j.jclepro.2015.12.087

Wu, C., Wang, Q., Xiang, J., Yu, M., Chang, Q., Gao, M., Sonomoto, K., 2015. Enhanced Productions 
and Recoveries of Ethanol and Methane from Food Waste by a Three-Stage Process. Energy and Fuels 29, 6494-6500. doi:10.1021/acs.energyfuels.5b01507

Wu, L.J., Kobayashi, T., Li, Y.Y., Xu, K.Q., 2015. Comparison of single-stage and temperature-phased two-stage anaerobic digestion of oily food waste. Energy Convers. Manag. 106, 1174-1182. doi:10.1016/j.enconman.2015.10.059

Yan, S., Chen, X., Wu, J., Wang, P., 2013. Pilot-scale production of fuel ethanol from concentrated food waste hydrolysates using Saccharomyces cerevisiae H058. Bioprocess Biosyst. Eng. 36, 937-946. doi:10.1007/s00449-012-0827-9

Yang, S., Li, Q., Zeng, Q., Zhang, J., Yu, Z., Liu, Z., 2012. Conversion of Solid Organic Wastes into Oil via Boettcherisca peregrine (Diptera: Sarcophagidae) Larvae and Optimization of Parameters for Biodiesel Production. PLoS One 7, 1-7. doi:10.1371/journal.pone.0045940

Yong, Z., Dong, Y., Zhang, X., Tan, T., 2015. Anaerobic co-digestion of food waste and straw for biogas production. Renew. Energy 78, 527-530. doi:10.1016/j.renene.2015.01.033

Yu, I.K.M., Tsang, D.C.W., Yip, A.C.K., Chen, S.S., Wang, L., Sik, Y., 2017. Catalytic valorization of starch-rich food waste into hydroxymethylfurfural ( HMF ): Controlling relative kinetics for high productivity. Bioresour. Technol. 237, 222-230. doi:10.1016/j.biortech.2017.01.017

Zhang, C., Xiao, G., Peng, L., Su, H., Tan, T., 2013. The anaerobic co-digestion of food waste and cattle manure. Bioresour. Technol. 129, 170-176. doi:10.1016/j.biortech.2012.10.138

Zhang, L., Lee, Y.W., Jahng, D., 2011. Anaerobic co-digestion of food waste and piggery wastewater: Focusing on the role of trace elements. Bioresour. Technol. 102, 5048-5059. doi:10.1016/j.biortech.2011.01.082

Zhang, Y., Banks, C.J., Heaven, S., 2012. Anaerobic digestion of two biodegradable municipal waste streams. J. Environ. Manage. 104, 166-174. doi:10.1016/j.jenvman.2012.03.043

Zhang, Z., O’Hara, I.M., Mundree, S., Gao, B., Ball, A.S., Zhu, N., Bai, Z., Jin, B., 2016. Biofuels from food processing wastes. Curr. Opin. Biotechnol. 38, 97-105. doi:10.1016/j.copbio.2016.01.010

Zhao, Y., Lu, W., Damgaard, A., Zhang, Y., Wang, H., 2015. Assessment of co-composting of sludge and woodchips in the perspective of environmental impacts (EASETECH). Waste Manag. 42, 55-60. doi:10.1016/j.wasman.2015.04.021

Zhou, Q., Shen, F., Yuan, H., Zou, D., Liu, Y., Zhu, B., Jaffu, M., Chufo, A., Li, X., 2014. Minimizing asynchronism to improve the performances of anaerobic co-digestion of food waste and corn stover. Bioresour. Technol. 166, 31-36. doi:10.1016/j.biortech.2014.04.074 